\title{
"The design and use of performance measurement innovations and organizational outcomes in Nigerian listed companies"
}

\begin{tabular}{ll} 
AUTHORS & $\begin{array}{l}\text { Folashade Owolabi (i) } \\
\text { Solabomi Ajibolade (i) } \\
\text { Uwalomwa Uwuigbe (i) } \\
\text { R }\end{array}$ \\
\hline ARTICLE INFO & $\begin{array}{l}\text { Folashade Owolabi, Solabomi Ajibolade and Uwalomwa Uwuigbe (2021). The } \\
\text { design and use of performance measurement innovations and organizational } \\
\text { outcomes in Nigerian listed companies. Problems and Perspectives in } \\
\text { Management, 19(2), 91-103. doi:10.21511/ppm.19(2).2021.08 }\end{array}$ \\
\hline DOI & http://dx.doi.org/10.21511/ppm.19(2).2021.08 \\
\hline RELEASED ON & Thursday, 13 May 2021 \\
\hline RECEIVED ON & Tuesday, 12 May 2020 \\
\hline ACCEPTED ON & Thursday, 22 October 2020 \\
\hline LICENSE & $\begin{array}{l}(c) \text { Er } \\
\text { This work is licensed under a Creative Commons Attribution 4.0 International } \\
\text { License }\end{array}$ \\
\hline JOURNAL & "Problems and Perspectives in Management" \\
\hline ISSN PRINT & $1727-7051$ \\
\hline ISSN ONLINE & $1810-5467$ \\
\hline PUBLISHER & LLC "Consulting Publishing Company "Business Perspectives" \\
\hline FOUNDER & LLC "Consulting Publishing Company "Business Perspectives"
\end{tabular}

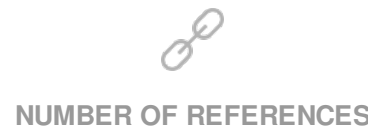

33
NUMBER OF FIGURES

1
NUMBER OF TABLES

8

(C) The author(s) 2021. This publication is an open access article. 


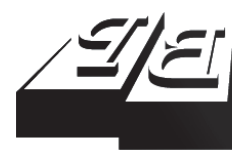

\section{BUSINESS PERSPECTIVES}

LLC "CPC "Business Perspectives" Hryhorii Skovoroda lane, 10, Sumy, 40022, Ukraine www.businessperspectives.org

Received on: $12^{\text {th }}$ of May, 2020 Accepted on: $22^{\text {nd }}$ of October, 2020 Published on: $13^{\text {th }}$ of May, 2021

(c) Folashade Owolabi, Solabomi Ajibolade, Uwalomwa Uwuigbe, 2021

Folashade Owolabi, M.Sc., Department of Accounting, College of Business and Social Sciences, Covenant University Ota, Nigeria. (Corresponding author)

Solabomi Ajibolade, Ph.D., Associate Professor, Accounting Department, Faculty of Management Sciences, University of Lagos, Lagos, Nigeria.

Uwalomwa Uwuigbe, Ph.D., Dean, Department of Accounting, College of Business and Social Sciences, Covenant University, Ota, Nigeria.
Folashade Owolabi (Nigeria), Solabomi Ajibolade (Nigeria),

Uwalomwa Uwuigbe (Nigeria)

\section{THE DESIGN AND USE} OF PERFORMANCE MEASUREMENT INNOVATIONS AND ORGANIZATIONAL OUTCOMES IN NIGERIAN LISTED COMPANIES

\begin{abstract}
Performance measurement innovations (PMI) provide frameworks for the improvement of organizational performance. While developed economies have widely accepted PMI, little is known about their design and use in developing economies. This study aimed to investigate the relationship between the design and use of PMI and organizational outcomes among listed firms in Nigeria. Partial least squares structural equation modeling was adopted for the analysis using cross-sectional survey data comprising 126 corporate managers in the sampled listed companies. The results showed that all the path coefficients for design of PMI and customer perspective $(\beta=0.325$, $p<0.0001)$, financial $(\beta=0.314, p<0.0001)$, internal business process $(\beta=0.346$, $p<0.0001)$, and learning and growth perspectives $(\beta=0.367, p<0.0001)$ were significantly positive. This suggests that designing performance measures to include a diversity of measurement incorporating financial and non-financial measures would positively affect organizational outcomes. Besides, diagnostic use was found to have a negative effect on customer perspective $(\beta=-0.315, p<0.01)$, while the interactive use $(\beta=0.411, p<0.01)$ of PMI demonstrated a positive effect on it. This implies that using PMIs in a diagnostic manner brings about a negative image of the customer perspective, but it is divergent for interactive use.
\end{abstract}

Keywords

performance, firm strategy, organizations, management control systems, management accounting, performance management, management

JEL Classification $\quad$ M14, M41

\section{INTRODUCTION}

Over the years, companies' organizational outcomes across the globe have been evaluated primarily on financial metrics such as return on capital employed, return on equity, and return on investment. However, the extant literature has shown that while financial measures remain the foremost performance evaluation technique of an organization, other important non-financial measures of performance serve as leading indicators of organizational success. For instance, Kaplan and Norton (1992) suggested three other perspectives besides the financial perspective: customer perspective, learning and growth perspective, and internal business process perspective, collectively known as the balanced scorecard. This was introduced to provide a holistic view of the performance of an organization. This led to a transition from the traditional performance measurement systems, which used only financial measures as the only basis of performance measurement to develop modern performance measurement frameworks, 
which now combines financial and non-financial measures of organizational outcomes. These frameworks are now variously referred to as strategic performance measurement systems (SPMS), contemporary performance measurement systems (CPMS), or performance measurement innovations (PMI). Performance measurement innovations are an aspect of management control systems and can be described as new techniques of managing performance involving financial and non-financial measures derived from the firm's strategy in evaluating organizational performance.

The gains of implementing such systems have been found from previous studies in Western countries (Guenther \& Heinicke, 2019); however, the studies on it in emerging economies are still very scanty. Furthermore, there is empirical evidence implying that the nature of design and use of performance measurement innovations could have a substantial effect on the financial performance of the organization (Acquaah, 2013), but this has not been sufficiently investigated within the purview of the Nigerian context (Owolabi et al., 2016). Besides, organizational outcomes have been commonly examined within the confinement of financial outcomes; hence, studying other outcomes like the three different perspectives of the balanced scorecard would contribute to the literature and how the design and use of performance measurement innovations influence organizational outcomes. This study examined the relationship between the design and use of performance measurement innovations and the balanced scorecard perspectives in the Nigerian listed companies.

\section{LITERATURE REVIEW}

Two major aspects of performance measurement innovations explored in this study are the design and the nature of the innovations' use. The design of performance measurement innovations is concerned with the broader measurement mix. This measurement mix complements traditional financial measures with a combination of several non-financial metrics that can express vital performance dimensions that may not be well represented by just the financial measures (Henri, 2006b; Ittner et al., 2003).

Besides, this study aligns with Simon's classification of performance measurement innovations in the Nigerian context. The two uses of control systems introduced by Simon (1995) dominate contemporary performance systems literature because they are seen as more applicable and specific to a business context. The uses are referred to as diagnostic and interactive uses. According to Simon (1995), diagnostic uses are described as the prescribed information systems employed by managers to oversee organizational outcomes and ameliorate variances from predetermined performance standards. However, Henri (2006a) referred to it as a negative force because it focuses more on errors and unfavorable variances. On the other hand, Simon (2000) described interactive uses as the official information systems by which man- agers get themselves to participate in their subordinates' decision-making activities. Koufterous et al. (2014) described this interactive use as progressive action. Some of the previous studies have claimed a relationship between such uses of performance measurement innovations and organizational outcomes (Acquaah, 2013; Koufteros et al., 2014). However, while extant literature argued that there is a relationship between the diagnostic use, interactive use of performance measurement innovations, and organizational outcomes, there are scanty studies in Nigeria that have tested this association.

Furthermore, Franco-Santos et al. (2012) argued that studies that have analyzed the effect of performance measurement innovations on organizational outcomes had measured performance in diverse ways, which they referred to as reported and perceived performance. Companies' reported performance is annual report-based and could be either financial or non-financial information, which includes accounting performance and market performance. Similarly, the perceived performance also consists of financial and non-financial information but reflects the respondents' perception to the research survey. This includes the perception of a boost in performance, attainment of strategic objectives, and customer performance. In this study, the perceived performance was adopted using balanced scorecard perspectives. 
The balanced scorecard perspectives are the customer, financial, internal business process, learning, and growth dimensions. According to Kaplan and Norton (1992), the customer perspective concerns an organization's image to customers; the financial perspective relates to financial success and the outlook of the organization to shareholders. The internal business process has its focus on the business processes organizations should excel at to meet the needs of shareholders and customers while learning and growth are associated with change and improvements in the organization to achieve her vision.

The contingency theory underpins this study. The theory is the main framework for organizational design (Donaldson, 2001). Kaplan and Mikes (2014) opined that the crux of a contingency theory is finding the "fit" between contextual factors and organizations' practices and establishing propositions of fit that will result in anticipated outcomes. According to Weill and Olson (1989), contingency theorists strived to establish the essential variables expected to influence organizational performance. Franco-Santos et al. (2012) in their systematic review added that past studies suggest that it is the way these performance innovations are designed, developed, and used that brings about performance improvements. Therefore, this study applies the contingency theory in explaining how organizational design and use of performance measurement innovations affect organizational outcomes of listed firms in Nigeria.

Empirically, Bisbe and Otley (2004) investigated the indirect relationship between interactive use of the management control system (MCS) and performance mediated by innovation among medium-sized manufacturing Spanish companies. The study found no significant indirect impact of the interactive use of MCS through innovation on performance. It was observed that while the study adopted the Simon's lever of control for the study, only the interactive use of control was tested in the study. Therefore, no empirical evidence was provided for the diagnostic use of controls. Braam and Nijssen (2004) assessed how balanced scorecard use influences firm performance among Dutch firms. Based on 41 respondents' data, the study found that while the balanced scorecard contributes significantly to overall firm perfor- mance, its implementation does not spontaneously improve firm performance. Tuomela (2005) examined different designs of control in a longitudinal field study related to the adoption and use of a new performance measurement system in a case company. It found that when performance measures are used in an interactive manner, they enhance strategic management quality. However, the study was a case study that requires a larger sample size to substantiate the findings. This is drawing from Çakmak and Akgün (2018) who opined that case studies are only generalizable to theoretical propositions but not to populations outside the cases investigated.

Henri (2006a) investigated the contribution of the interactive and diagnostic uses of performance measurement innovations to organizational performance through four capabilities. It was a survey designed study with copies of questionnaires served to top management teams of small and medium manufacturing Canadian firms. The study found that interactive use of performance measurement innovations has a positive relationship with organizational performance, contrary to diagnostic use. Widener (2007) investigated the effect of diagnostic and interactive uses of performance measurement innovations on cost and benefits and how this interaction affects performance. Using data from 122 Chief Financial Officers of selected US firms, the study's finding showed that control systems are directly related to both benefit and cost. It also found a direct but weak relationship between control systems and performance. Koufteros et al. (2014) investigated the interaction between the uses of performance measurement innovations, organizational capabilities, target performance, and organizational performance. The use of performance measurement innovations was operationalized using Simon's levers of control framework, while proxies of organizational performance were both subjective and objective measures. The scope of the study covered 386 Italian firms. The study found that performance measurement innovations' diagnostic and interactive uses are positive forces towards organizational capabilities and performance. Lopez-Valeiras et al. (2016) examined how management control systems' interactive use directly influenced organizational processes and innovation. The postulated relationships were tested using the Iberian agri- 
food industry, and partial least squares regression was applied in arriving at the results. Empirical findings from the study suggested that interactive use of management control systems promotes process and organizational innovation. Guenther and Heinicke (2019) explored the relationship between performance measurement innovation design, use, and performance measurement innovation benefits in selected German midsized firms. In the cross-sectional study, it was found that a more sophisticated designed performance measurement system is dysfunctional with diagnostic use while beneficial for interactive use, and the fit between the design and use has an impact on the performance measurement systems benefits.

Ajibolade (2013) examined the relationship between the performance measurement design, product costing system design, three organization's variables, and performance in the Nigerian manufacturing listed companies. The results showed a significant and positive correlation between organization performance and performance measurement designs. Acquaah (2013) investigated the relationship between the use of management control systems and perceived performance in Ghanaian businesses and found a positive and significant relationship between the interactive use and financial performance and a positive but insignificant relationship between the diagnostic use and financial performance. Mohamed et al. (2014) investigated the influence of the design and use of Strategic Performance Measurement Systems (SPMS) on organizational capabilities in Malaysian listed companies. Data were gathered from 145 respondents, and the results show that SPMS design and use have a significant positive relationship with organizational capabilities.

A summary of related literature is presented in Table 1.

\section{DATA AND METHODS}

This study adopted the cross-sectional research design using the survey method as the instrument of data gathering. The survey instrument was the questionnaire adapted from previous studies (Guenther \& Heinicke, 2019; Soderberg et al., 2011; Speckbacher et al., 2003; Nisha, 2017). This study's population consisted of all active firms listed on the Nigerian Stock Exchange (NSE) as of $31^{\text {st }}$ December 2018. Listed firms were the focus of this study because they are more structured and use formal controls like the performance measurement systems (Ajibolade, 2013; Oyerogba, 2015; Guenther \& Heinicke, 2019). The population consisted of all organizations listed on the premium and main board of the Nigerian Stock Exchange (NSE). However, all listed funds, companies that have just been recently acquired, and those that have not submitted their annual reports for three consecutive years were all exempted. In total, 106 companies constituted the population. From that, the sample size was determined using the Taro Yamane formula to derive 84 companies.

The target respondents for this study were the senior and middle-level managers of the listed companies. The middle-level managers were also included because they are likely to be exposed to the use of contemporary performance measurement systems by senior management (Webster, 2006). A copy of the questionnaire was administered to 3 managers of each of the sampled organizations resulting in 252 total copies administered to $84 \mathrm{com}$ panies. These managers must be in the departments that are connected with the perspectives of the balanced scorecard. These are finance, production, admin, or marketing. The method of data analysis was the partial least squares structural equation modeling (PLS-SEM) technique. An advantage of this method is that datasets are not required to be normally distributed, and it works with relatively small sample sizes (Webster, 2006; Kazár, 2013). The SmartPLS 3.0 was used to run the algorithms and another routine for the partial least squares multivariate analyses.

The independent variables were the design, diagnostic use, and interactive use of performance measurement systems. In contrast, the dependent variable was organization outcomes operationalized as the balanced scorecard's four perspectives, namely customer, financial, internal business, and learning and growth perspectives. The relationship between design and each of the four perspectives was Hypotheses 1a-1d, that of diagnostic use and the perspectives were Hypotheses $2 \mathrm{a}-2 \mathrm{~d}$, and interactive use and the perspectives were Hypotheses 3a-3d. 
Table 1. Summary of relevant studies on diagnostic and interactive uses, design of performance measurement innovations, and organizational outcomes

\begin{tabular}{|c|c|c|c|c|c|c|c|}
\hline $\mathrm{S} / \mathrm{N}$ & Authors & Objective(s) & $\begin{array}{c}\text { Sample size/ } \\
\text { scope }\end{array}$ & Variables & Methodology & Result & Critique \\
\hline 1 & $\begin{array}{c}\text { Bisbe } \\
\text { and Otley } \\
\text { (2004) }\end{array}$ & $\begin{array}{l}\text { The study investigated the indirect } \\
\text { relationship between interactive use } \\
\text { of management control system and } \\
\text { performance mediated by innovation } \\
\text { among medium-sized, mature } \\
\text { manufacturing Spanish firms }\end{array}$ & $\begin{array}{c}\text { Spanish } \\
\text { manufacturing } \\
\text { firms }\end{array}$ & $\begin{array}{l}\text { Interactive use of } \\
\text { management control system, } \\
\text { performance, and innovation }\end{array}$ & $\begin{array}{l}\text { Moderated } \\
\text { regression } \\
\text { analysis }\end{array}$ & $\begin{array}{l}\text { The study found no significant } \\
\text { indirect impact of interactive use } \\
\text { of MCS through innovation on } \\
\text { performance }\end{array}$ & $\begin{array}{l}\text { There was no empirical evidence } \\
\text { provided for the diagnostic use of } \\
\text { controls }\end{array}$ \\
\hline 2 & $\begin{array}{l}\text { Braam and } \\
\text { Nijssen } \\
(2004)\end{array}$ & $\begin{array}{l}\text { It assessed how BSC use influences firm } \\
\text { performance among Dutch firms }\end{array}$ & $\begin{array}{l}41 \text { selected } \\
\text { Dutch firms }\end{array}$ & $\begin{array}{c}\text { Balance of the BSC measures, } \\
\text { financial measures like return } \\
\text { on investment, non-financial } \\
\text { measures }\end{array}$ & $\begin{array}{l}\text { Regression } \\
\text { analysis }\end{array}$ & $\begin{array}{l}\text { The study found that while the } \\
\text { balanced scorecard contributes } \\
\text { significantly to overall firm } \\
\text { performance, its implementation } \\
\text { does not spontaneously improve } \\
\text { firm performance }\end{array}$ & $\begin{array}{c}\text { The findings from the study implied } \\
\text { indirect effects between the use of } \\
\text { balanced scorecard and performance } \\
\text { but not examined in the study }\end{array}$ \\
\hline 3 & $\begin{array}{l}\text { Tuomela } \\
\text { (2005) }\end{array}$ & $\begin{array}{l}\text { The study examined different designs of } \\
\text { control in a longitudinal field study as it } \\
\text { relates to the introduction and use of a } \\
\text { new performance measurement system at } \\
\text { one case company }\end{array}$ & Case study & $\begin{array}{l}\text { Interactive and diagnostic } \\
\text { use of strategic performance } \\
\text { measurement system }\end{array}$ & $\begin{array}{l}\text { Qualitative } \\
\text { analysis }\end{array}$ & $\begin{array}{l}\text { The study found that strategic } \\
\text { performance measurement systems } \\
\text { can be used both diagnostically } \\
\text { and interactively. Interactive use } \\
\text { enhances the quality of strategic } \\
\text { management }\end{array}$ & $\begin{array}{l}\text { The study was a case study that } \\
\text { requires a larger sample size to } \\
\text { substantiate the findings. This is } \\
\text { drawing from Çakmak and Akgün } \\
\text { (2018) who opined that case studies, } \\
\text { like experiments, are generalizable to } \\
\text { theoretical propositions and not to } \\
\text { populations or universes beyond the } \\
\text { cases studied }\end{array}$ \\
\hline 4 & $\begin{array}{l}\text { Henri } \\
(2006 a)\end{array}$ & $\begin{array}{l}\text { Investigation of the contribution of the } \\
\text { interactive and diagnostic use of PMI to } \\
\text { organizational performance }\end{array}$ & $\begin{array}{c}1,692 \text { Canadian } \\
\text { firms }\end{array}$ & $\begin{array}{c}\text { Interactive and diagnostic use } \\
\text { of PMI, Market orientation, } \\
\text { entrepreneurship, } \\
\text { innovativeness, and } \\
\text { organizational learning as } \\
\text { moderating variables and } \\
\text { organizational performance }\end{array}$ & $\begin{array}{c}\text { Structural } \\
\text { Equation } \\
\text { Modelling (SEM) }\end{array}$ & $\begin{array}{l}\text { The results suggest that PMI used } \\
\text { interactively contribute positively } \\
\text { to the organizational performance } \\
\text { while it is the opposite for diagnostic } \\
\text { use }\end{array}$ & $\begin{array}{l}\text { The performance was measured } \\
\text { using only the financial dimension, } \\
\text { which had been established in } \\
\text { management accounting literature } \\
\text { that it is backward-looking. Hence, } \\
\text { additional success indicators would } \\
\text { present a more insightful discussion }\end{array}$ \\
\hline 5 & $\begin{array}{l}\text { Widener } \\
\text { (2007) }\end{array}$ & $\begin{array}{l}\text { The article examined the influence of both } \\
\text { the diagnostic and interactive uses of } \\
\text { performance measurement innovations on } \\
\text { cost and benefits and how this interaction } \\
\text { affects performance }\end{array}$ & $\begin{array}{l}122 \text { Chief } \\
\text { Financial } \\
\text { Officers of } \\
\text { selected US } \\
\quad \text { firms }\end{array}$ & $\begin{array}{c}\text { Beliefs system, boundary } \\
\text { system, diagnostic controls, } \\
\text { and interactive controls, } \\
\text { organizational learning, } \\
\text { consumption of management } \\
\text { attention }\end{array}$ & $\begin{array}{l}\text { Structural } \\
\text { equation } \\
\text { modeling }\end{array}$ & $\begin{array}{c}\text { Control systems, which include } \\
\text { beliefs system, boundary system, } \\
\text { diagnostic controls, and interactive } \\
\text { controls, are associated with } \\
\text { a benefit operationalized as } \\
\text { organizational learning, and a cost } \\
\text { operationalized as consumption of } \\
\text { management attention }\end{array}$ & $\begin{array}{l}\text { The generalizability of results is } \\
\text { not extendable to other population } \\
\text { outside the examined sample context }\end{array}$ \\
\hline 6 & $\begin{array}{l}\text { Koufteros, } \\
\text { Verghese, } \\
\text { and } \\
\text { Lucianetti } \\
\text { (2014) }\end{array}$ & $\begin{array}{c}\text { Authors investigated the interaction } \\
\text { between the uses of performance } \\
\text { measurement innovations, organizational } \\
\text { capabilities, target performance, and } \\
\text { organizational performance }\end{array}$ & 386 Italian firms & $\begin{array}{c}\text { Interactive use, diagnostic } \\
\text { use, organizational } \\
\text { capabilities, and organization } \\
\text { performance }\end{array}$ & $\begin{array}{l}\text { Fixed effect and } \\
\text { random effect } \\
\text { regression }\end{array}$ & $\begin{array}{l}\text { The study found that the diagnostic } \\
\text { and interactive uses of performance } \\
\text { measurement innovations } \\
\text { contribute positively towards } \\
\text { organizational capabilities and } \\
\text { performance }\end{array}$ & $\begin{array}{c}\text { Further studies in a different context } \\
\text { to validate results }\end{array}$ \\
\hline
\end{tabular}




\begin{tabular}{|c|c|c|c|c|c|c|c|}
\hline$S / N$ & Authors & Objective(s) & $\begin{array}{c}\text { Sample size/ } \\
\text { scope }\end{array}$ & Variables & Methodology & Result & Critique \\
\hline 7 & $\begin{array}{l}\text { Lopez- } \\
\text { Valeiras, } \\
\text { Gonzalez- } \\
\text { Sanchez, } \\
\text { and } \\
\text { Gomez- } \\
\text { Conde } \\
(2016)\end{array}$ & $\begin{array}{l}\text { The paper examined how the interactive } \\
\text { use of management control systems } \\
\text { directly influenced the process and } \\
\text { organizational innovation. It also } \\
\text { investigated how interactive use of } \\
\text { management control play a moderating } \\
\text { role in the relationship between } \\
\text { innovation and financial performance }\end{array}$ & $\begin{array}{l}230 \text { firms in the } \\
\text { Iberian agri- } \\
\text { food industry }\end{array}$ & $\begin{array}{c}\text { Interactive use of } \\
\text { management control systems, } \\
\text { process and organizational } \\
\text { innovation, financial } \\
\text { performance }\end{array}$ & $\begin{array}{l}\text { Partial least } \\
\text { squares } \\
\text { regression }\end{array}$ & $\begin{array}{l}\text { The interactive use of management } \\
\text { control systems promotes process } \\
\text { and organizational innovation. It also } \\
\text { added that the interactive use of } \\
\text { management control systems could } \\
\text { moderate the relationship between } \\
\text { a process innovation and financial } \\
\text { performance. }\end{array}$ & $\begin{array}{l}\text { No empirical evidence provided for } \\
\text { diagnostic use }\end{array}$ \\
\hline 8 & $\begin{array}{l}\text { Guenther } \\
\text { and } \\
\text { Heinicke } \\
\text { (2019) }\end{array}$ & $\begin{array}{c}\text { The study explored the relationship } \\
\text { between PMI design, use, and PMI } \\
\text { benefits in selected German midsized } \\
\text { firms }\end{array}$ & $\begin{array}{l}276 \text { German } \\
\text { midsized firms }\end{array}$ & $\begin{array}{c}\text { Interactive and diagnostic } \\
\text { control system, performance } \\
\text { measurement system benefits }\end{array}$ & $\begin{array}{l}\text { Structural } \\
\text { equation } \\
\text { modeling, } \\
\text { polynomial } \\
\text { regression }\end{array}$ & $\begin{array}{l}\text { The study found that both } \\
\text { diagnostic and interactive uses of } \\
\text { performance measurement systems } \\
\text { have a positive and significant } \\
\text { relationship with performance } \\
\text { measurement systems. However, } \\
\text { the impact of interactive use is more } \\
\text { on the performance measurement } \\
\text { systems benefits. It also found PMI } \\
\text { design positively moderates the } \\
\text { relationship between the use of PMI } \\
\text { and PMI benefits }\end{array}$ & $\begin{array}{l}\text { The study was specific to German } \\
\text { small and medium firms, which may } \\
\text { be limited in generalizability to other } \\
\text { geographical contexts }\end{array}$ \\
\hline 9 & $\begin{array}{l}\text { Acquaah } \\
\text { (2013) }\end{array}$ & $\begin{array}{l}\text { It examined the relationship between the } \\
\text { use of management control systems and } \\
\text { perceived performance and compared } \\
\text { the result between family and non-family } \\
\text { businesses in Ghana }\end{array}$ & $\begin{array}{c}50 \text { family } \\
\text { businesses and } \\
50 \text { non-family } \\
\text { businesses }\end{array}$ & $\begin{array}{c}\text { An interactive control } \\
\text { system, diagnostic control } \\
\text { system, and dynamic tension } \\
\text { as independent variables. } \\
\text { Perceived performance as } \\
\text { the dependent variable, while } \\
\text { competitive strategy was a } \\
\text { mediating variable }\end{array}$ & $\begin{array}{l}\text { Mediated } \\
\text { regression } \\
\text { analysis }\end{array}$ & $\begin{array}{l}\text { It found a positive and significant } \\
\text { relationship between the interactive } \\
\text { use and financial performance and a } \\
\text { positive but insignificant relationship } \\
\text { between the diagnostic use and } \\
\text { financial performance }\end{array}$ & $\begin{array}{l}\text { The study used only Ghana as the } \\
\text { study scope, and the generalizability } \\
\text { of findings is limited. Also, only } \\
\text { financial metrics were used to } \\
\text { operationalize performance }\end{array}$ \\
\hline 10 & $\begin{array}{l}\text { Ajibolade } \\
(2013)\end{array}$ & $\begin{array}{l}\text { The study examined the relationships } \\
\text { between the performance measurement } \\
\text { systems design, three company's } \\
\text { contextual variables, and performance } \\
\text { in the Nigerian manufacturing listed } \\
\text { companies }\end{array}$ & $\begin{array}{c:}144 \\
\text { manufacturing } \\
\text { companies in } \\
\text { Nigeria }\end{array}$ & $\begin{array}{c}\text { Performance measurement } \\
\text { design, product costing, } \\
\text { perceived environmental } \\
\text { uncertainty (PEU), } \\
\text { decentralization and } \\
\text { technology as independent } \\
\text { variables and organizational } \\
\text { performance }\end{array}$ & $\begin{array}{l}\text { Moderation } \\
\text { regression } \\
\text { analysis }\end{array}$ & $\begin{array}{l}\text { The result showed a significant } \\
\text { positive and strong correlation } \\
\text { between company performance and } \\
\text { performance measurement design }\end{array}$ & $\begin{array}{l}\text { The study did not investigate the use } \\
\text { dimension of such systems }\end{array}$ \\
\hline 11 & $\begin{array}{l}\text { Mohamed, } \\
\text { Hui, } \\
\text { Rahman, } \\
\text { and Aziz } \\
(2014)\end{array}$ & $\begin{array}{l}\text { The research paper studied the } \\
\text { influence of the design and use of } \\
\text { Strategic Performance Measurement } \\
\text { Systems (SPMS) on organizational } \\
\text { capabilities, namely market orientation, } \\
\text { organizational learning, innovation, and } \\
\text { entrepreneurship in Malaysian listed } \\
\text { companies }\end{array}$ & $\begin{array}{l}145 \text { Malaysian } \\
\text { listed companies }\end{array}$ & $\begin{array}{l}\text { Choice of a performance } \\
\text { measure, market } \\
\text { orientation, organizational } \\
\text { learning, innovation, and } \\
\text { entrepreneurship }\end{array}$ & $\begin{array}{l}\text { Hierarchical } \\
\text { regression } \\
\text { analysis }\end{array}$ & $\begin{array}{l}\text { SPMS design and use have a positive } \\
\text { and significant relationship with } \\
\text { organizational capabilities }\end{array}$ & $\begin{array}{l}\text { Other proxies of organizational } \\
\text { outcomes could be examined }\end{array}$ \\
\hline
\end{tabular}
companies 


\section{RESULTS}

The senior and middle-level managers of the sampled listed companies were the participants of the survey. A total of 135 copies of the questionnaire were returned, indicating a $53.6 \%$ response rate. However, only 126 of the responses were suitable for further analyses. This response rate is common in management accounting research (Hiebl \& Richter, 2018).

The PLS-SEM was used to analyze hypothesized relationships and derive a path model. Generally, path models are designed in two stages of models, namely the measurement and structural models. All the indicators for the constructs were included in a measurement model to run the PLS algorithm. However, the first measurement model did not pass the quality tests, so indicators for each latent variable were removed by running the PLS algorithm until a suitable measurement model was achieved. The final measurement model was eventually derived and included thirty items for all the constructs. This measurement model was then assessed in terms of the quality criteria. The measurement model's quality was assessed using preliminary qualities such as indicator reliability, convergent reliability, internal consistency, and discriminant validity. The results are shown in Tables 2 and 3.
The results of the Cronbach's alpha, AVE, and CR are presented in Table 2. The Cronbach's alpha, which evaluated the items' reliability, is considered satisfactory at 0.7 (Oyerinde, 2011; Uwuigbe, 2011). The convergent reliability measured using the AVE should be higher than 0.5, and this was also established. The internal consistency assessed using the composite reliability must have values larger than 0.7 to be acceptable, and this condition was satisfied.

The discriminant validity was measured using the Heterotrait-Monotrait (HTMT) ratio of correlations. The constructs' threshold values should not be larger than 0.85 (Henseler et al., 2015). The HTMT ratios presented in Table 3 show that none of the values is higher than 0.85 .

Multivariate structural equation modeling was used in testing the hypotheses of this study. The significance in hypothesized relationships was tested using the path coefficient statistics presented in Tables 4 and 5 and Figure 1. Figure 1 depicts the final structural model showing the significant paths.

From Table 4, all the hypothesized paths for the design and organizational outcomes constructs were significant at a $95 \%$ confidence level. The standardized beta and p-value for each of the

Table 2. Quality assessment for the final measurement model

\begin{tabular}{|c|c|c|c|}
\hline Constructs & Cronbach's Alpha & Composite Reliability (CR) & Average Variance Extracted (AVE) \\
\hline Customer perspective & 0.831 & 0.899 & 0.748 \\
\hline Design of PMI & 0.711 & 0.814 & 0.524 \\
\hline Diagnostic use & 0.925 & 0.942 & 0.802 \\
\hline Financial perspective & 0.906 & 0.933 & 0.779 \\
\hline Interactive use & 0.942 & 0.953 & 0.743 \\
\hline Internal business process & 0.882 & 0.926 & 0.808 \\
\hline Learning and growth perspective & 0.856 & 0.895 & 0.633 \\
\hline
\end{tabular}

Table 3. HTMT ratios

\begin{tabular}{|c|c|c|c|c|c|c|c|}
\hline Constructs & $\begin{array}{l}\text { Customer } \\
\text { perspective }\end{array}$ & $\begin{array}{l}\text { Design of } \\
\text { PMI }\end{array}$ & $\begin{array}{c}\text { Diagnostic } \\
\text { use }\end{array}$ & $\begin{array}{c}\text { Financial } \\
\text { perspective }\end{array}$ & $\begin{array}{c}\text { Interactive } \\
\text { use }\end{array}$ & $\begin{array}{c}\text { Internal } \\
\text { business } \\
\text { process }\end{array}$ & $\begin{array}{l}\text { Learning } \\
\text { and growth } \\
\text { perspective }\end{array}$ \\
\hline Customer perspective & - & - & - & - & - & - & - \\
\hline Design of PMI & 0.449 & - & - & - & - & - & - \\
\hline Diagnostic use & 0.051 & 0.261 & - & - & - & - & - \\
\hline Financial perspective & 0.385 & 0.305 & 0.106 & - & - & - & - \\
\hline Interactive use & 0.321 & 0.343 & 0.723 & 0.092 & - & - & - \\
\hline Internal business process & 0.650 & 0.468 & 0.176 & 0.284 & 0.354 & - & - \\
\hline $\begin{array}{l}\text { Learning and growth } \\
\text { perspective }\end{array}$ & 0.644 & 0.402 & 0.078 & 0.534 & 0.151 & 0.845 & - \\
\hline
\end{tabular}




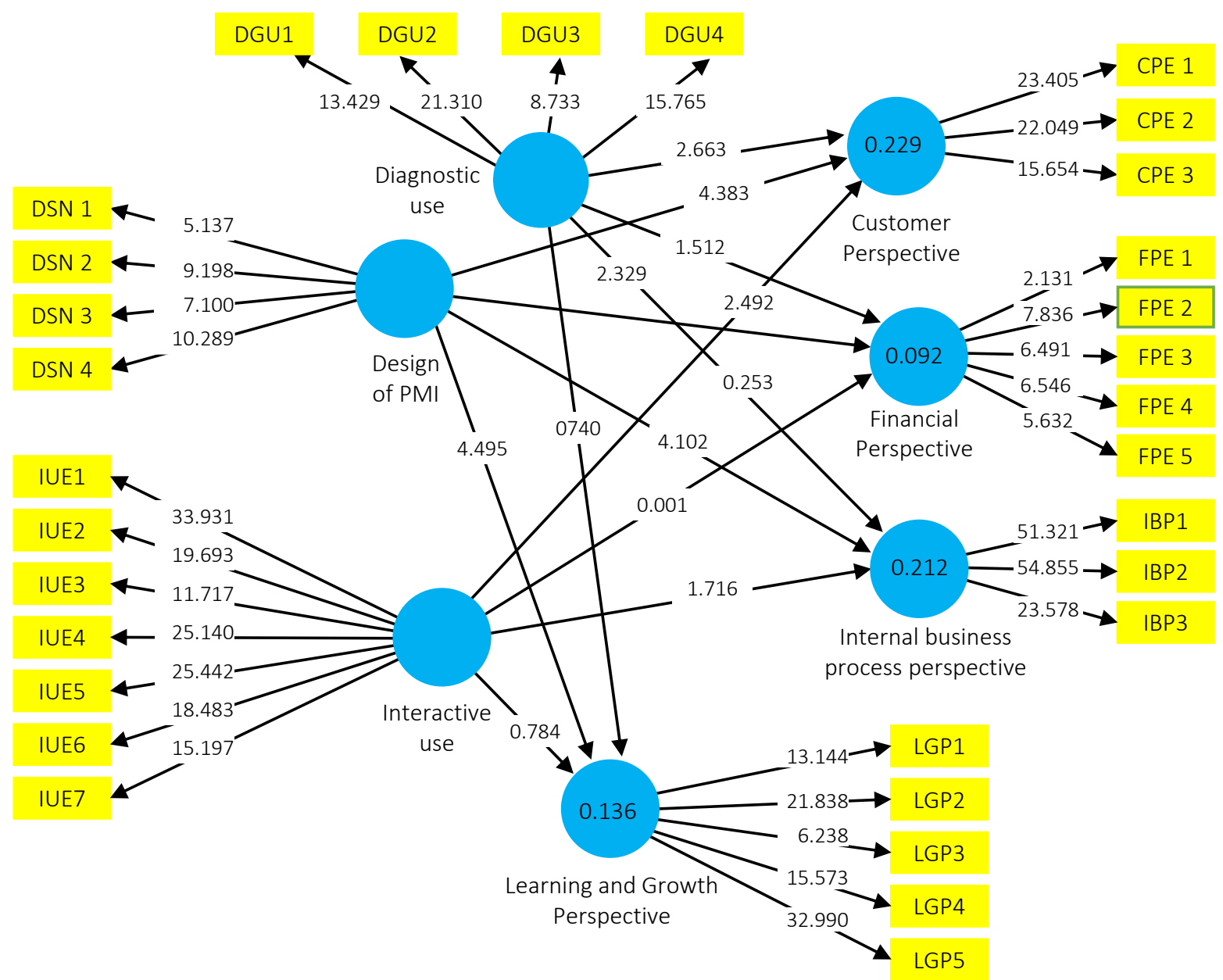

Note: Description in Table A1 (Appendix).

Figure 1. Final bootstrapped structural model showing the significance

Table 4. Path coefficients for design and organizational outcomes

\begin{tabular}{l|c|c:c:c}
\hline \multicolumn{1}{c}{ Hypothesized relationships } & Standard beta & Standard error & t-statistics & $\boldsymbol{p}$-value \\
\hline Design of PMI $\rightarrow$ Customer perspective & 0.325 & 0.072 & $4.365^{* * *}$ & $<0.001$ \\
\hline Design of PMI $\rightarrow$ Financial perspective & 0.314 & 0.087 & $3.485^{* * *}$ & $<0.001$ \\
Design of PMI $\rightarrow$ Internal business process perspective & 0.346 & 0.082 & $4.226^{* * *}$ & $<0.001$ \\
Design of PMI $\rightarrow$ Learning and growth perspective & 0.367 & 0.075 & $4.7^{* * *}$ & $<0.001$ \\
\hline
\end{tabular}

Note: Statistical significance: $* * * p<0.01$ level.

Table 5. Path coefficients for nature of use and organizational outcomes

\begin{tabular}{|c|c|c|c|c|}
\hline Hypothesized relationships & Standard beta & Standard error & t-statistics & $p$-value \\
\hline Diagnostic use $\rightarrow$ Customer perspective & -0.315 & 0.108 & $2.957 * * *$ & 0.003 \\
\hline Diagnostic use $\rightarrow$ Financial perspective & -0.128 & 0.088 & 1.493 & 0.135 \\
\hline Diagnostic use $\rightarrow$ Internal business process & -0.043 & 0.166 & 0.244 & 0.807 \\
\hline Diagnostic use $\rightarrow$ Learning and growth perspective & -0.12 & 0.163 & 0.696 & 0.486 \\
\hline Interactive use $\rightarrow$ Customer perspective & 0.411 & 0.148 & $2.762 * * *$ & 0.006 \\
\hline Interactive use $\rightarrow$ Financial perspective & 0.024 & 0.1 & 0.21 & 0.834 \\
\hline Interactive use $\rightarrow$ Internal business process & 0.274 & 0.147 & 1.759 & 0.079 \\
\hline Interactive use $\rightarrow$ Learning and growth perspective & 0.131 & 0.14 & 0.835 & 0.404 \\
\hline
\end{tabular}

Note: Statistical significance: ${ }^{* *} p<0.01$ level. 
Table 6. Coefficient of determination and predictive relevance

\begin{tabular}{l|c|c|c}
\hline \multicolumn{1}{c}{ Construct } & $\mathbf{R}^{\mathbf{2}}$ & $\boldsymbol{p}$-value & $\mathbf{Q}^{\mathbf{2}}$ \\
\hline Customer perspective & 0.233 & 0.004 & 0.143 \\
Financial perspective & 0.095 & 0.056 & 0.058 \\
\hline Internal business process & 0.220 & 0.005 & 0.150 \\
\hline Learning and growth perspective & 0.142 & 0.009 & 0.073 \\
\hline
\end{tabular}

Table 7. Inner Variance Inflation Factor (VIF)

\begin{tabular}{|c|c|c|c|c|c|c|c|}
\hline Construct & $\begin{array}{l}\text { Customer } \\
\text { perspective }\end{array}$ & $\begin{array}{c}\text { Design of } \\
\text { PMI }\end{array}$ & $\begin{array}{l}\text { Diagnostic } \\
\text { use }\end{array}$ & $\begin{array}{c}\text { Financial } \\
\text { perspective }\end{array}$ & $\begin{array}{c}\text { Interactive } \\
\text { use }\end{array}$ & $\begin{array}{l}\text { Internal } \\
\text { business } \\
\text { process }\end{array}$ & $\begin{array}{l}\text { Learning and growth } \\
\text { perspective }\end{array}$ \\
\hline Design of PMI & 1.090 & - & - & 1.090 & - & 1.090 & 1.090 \\
\hline Diagnostic use & 1.753 & - & - & 1.753 & - & 1.753 & 1.753 \\
\hline Interactive use & 1.847 & - & - & 1.847 & - & 1.847 & 1.847 \\
\hline
\end{tabular}

subgroups are also presented in the table. The $p$-value for each of the hypothesized relationship was less than 0.01 . This result implies that the design of performance measurement innovations has a significant influence on all the four perspectives, which are measures of organizational outcomes.

In terms of the nature of the use of performance measurement innovations, it can be seen from Table 5 that diagnostic use showed a significant negative relationship with the customer perspective. In contrast, the interactive use presented a significant positive relationship with the customer perspective. The standardized beta is also presented in the table. Other hypothesized relationships were not significant.

The overall model was evaluated using the coefficient of determination $\left(\mathrm{R}^{2}\right)$, predictive relevance $\left(\mathrm{Q}^{2}\right)$, and the Variance Inflation Factor (VIF) values, as presented in Tables 6 and 7. As shown in Table $6, \mathrm{R}^{2}$, which measures the joint impact of the independent variables, had values of $0.233,0.095$, 0.220 , and 0.142 for customer, financial, internal business process, and learning and growth perspectives. This implies that the design and use of performance measurement innovations can jointly explain variation in organizational outcomes. Although the values were relatively low, they were significant at $p$-value $<0.05$ except for the financial perspective, which had a $p$-value of 0.056 . The predictive relevance, $\mathrm{Q}^{2}$, was derived by running the blindfold procedure on the SmartPLS after obtaining the structural model. According to Hair et al. (2019), $Q^{2}$ measures a structural model's predictive accuracy, and values above zero are meaningful. That is, such a model has predictive relevance for a specific endogenous construct. For this study's structural model, the $\mathrm{Q}^{2}$ values are all higher than zero, as shown in Table 6.

The VIF values, as shown in Table 7, were all less than 3 , showing there were no collinearity issues with the inner model.

\section{DISCUSSION}

Firstly, this study investigated the relationship between the design of performance measurement innovations and organizational outcomes in Nigerian listed companies. The study found a significant positive relationship between the exogenous and endogenous variables. This suggests that designing performance measurement innovations with greater measurement diversity could positively and significantly contribute to the image of customer perspective, financial performance, internal business processes, and learning and growth perspective of an organization, which are the four dimensions of organizational outcomes examined. The results showed that the design of performance measurement innovations could explain a variation of $31.4 \%, 32.5 \%, 34.6 \%$, and $36.7 \%$ on the financial, customer, internal business process and learning, and growth perspectives of an organization, respectively. This result is consistent with those of existing studies in both developed and developing countries (Ajibolade, 2013; Guenther \& Heinicke, 2019). Ajibolade (2013) found a positive correlation between performance measurement system design and organizational performance in Nigeria. However, the organizational performance was based on only financial dimen- 
sions, while this study extends the scope by examining other non-financial variables of organizational success. Guenther and Heinicke (2019) also opined that PMI's design could offer benefits such as improved customer focus, identifying business process reengineering opportunities, and improving company results in the long term, especially when it is used interactively within the context of German midsized companies.

Secondly, the relationship between the use of performance measurement innovations and organizational outcomes in Nigerian listed companies was also examined. The results showed a significant negative relationship between the diagnostic uses and customer perspective with a path coefficient $(-0.315)$, while the relationship between the diagnostic use and other organizational outcomes were not significant. Besides, the relationship between interactive use and customer perspective was positively significant with a path coefficient of $(+0.411)$, while it was not significant with other organizational outcomes variables. This result implies that using performance measurement innovations in a diagnostic manner may bring about a negative image of the customer perspective. Similarly, Braam and Nijssen (2004) argued that using a balanced scorecard in a diagnostic manner and not aligning it to strategy will deter performance and may even lessen performance.
On the contrary, interactively using performance measures enhances listed organizations' outcomes in Nigeria, especially customer perspectives. The findings of this study also corroborate the findings of Acquaah (2013), Guenther and Heinicke (2019), Henri (2006a), Koufterous et al. (2014), and Lopez-Valeiras et al. (2016). Acquaah (2013) found a positive and significant relationship between interactive use and financial performance and a positive but insignificant relationship between diagnostic use and financial performance using Ghanaian selected companies. The result reported for diagnostic use was not consistent with the findings of this study, and this could be that while this study focused on listed firms in Nigeria, that of Aquaah (2013) focused on both family and non-family businesses in Ghana. However, Henri (2006a) reported that performance measurement innovation used interactively contributes positively to the organizational performance while it is the opposite for diagnostic use, which confirms this study's result. Nonetheless, Koufteros et al. (2014) found that performance measurement innovations' diagnostic and interactive uses contribute positively towards organizational capabilities and performance. Also, Lopez-Valeiras et al. (2016) found that MCS's interactive use promotes process and organizational innovation in Italian firms. The contradictory findings of the diagnostic use of performance measurement innovations require further investigations.

\section{CONCLUSION}

This study provided empirical evidence on the relationship between the design, use of performance measurement innovations, and organizational outcome within the context of an emerging economy. From the results, it was observed that the diversity of the design of performance measurement innovations could influence organizational outcomes such as customer, internal business, and learning and growth perspectives positively. The findings show that organizational outcomes are enhanced when performance measurement innovations are designed to be more balanced by including both financial and non-financial measures. It also established that both diagnostic and interactive uses of PMIs impact the non-financial dimensions of organizational outcomes. However, while this impact is significant in the image of the customer perspective, it is insignificant on the business processes and learning and growth perspectives. Furthermore, while diagnostic use had a negative effect on the customer perspective, interactive uses of PMI demonstrated a positive effect on it. Therefore, it is recommended that PMIs used by Nigerian listed companies should be designed to include a diversity of measurements that incorporate financial and non-financial measures to equip managers with more holistic performance evaluation details needed to support decisions and thereby improve organizational outcomes. More so, these innovations should be used by managers more interactively, in such a manner that would encourage communication between them and their subordinates to enhance loyalty to strategic objectives. This study used the perceived organizational outcomes; future studies could use reported performance such as the annual report. 


\section{AUTHOR CONTRIBUTIONS}

Conceptualization: Folashade Owolabi.

Formal analysis: Folashade Owolabi.

Methodology: Folashade Owolabi.

Resources: Solabomi Ajibolade, Uwalomwa Uwuigbe.

Software: Folashade Owolabi.

Supervision: Solabomi Ajibolade, Uwalomwa Uwuigbe.

Validation: Folashade Owolabi.

Visualization: Solabomi Ajibolade.

Writing - original draft: Folashade Owolabi.

Writing - review \& editing: Folashade Owolabi, Uwalomwa Uwuigbe.

\section{ACKNOWLEDGMENT}

The authors sincerely appreciate Covenant University, Nigeria, for sponsoring this publication.

\section{REFERENCES}

1. Acquaah, M. (2013). Management control systems, business strategy and performance: A comparative analysis of family and non-family businesses in a transition economy in sub-Saharan Africa. Journal of Family Business Strategy, 4(2), 131-146. https://doi.org/10.1016/j. jfbs.2013.03.002

2. Ajibolade, S. O. (2013). Management accounting systems design and company performance in Nigerian manufacturing companies: A contingency theory perspective. British Journal of Arts and Social Sciences, 14(2), 228-244. Retrieved from https:// pdfs.semanticscholar.org/8fcb/fb459454aa3e21c3b23b67057dff4ea 1789c.pdf

3. Bisbe, J., \& Otley, D. (2004). The effects of the interactive use of management control systems on product innovation. Accounting, Organizations and Society, 29, 709-737. https://doi.org/10.1016/j. aos.2003.10.010

4. Braam, G. J. M., \& Nijssen, E. J. (2004). Performance effects of using the balanced scorecard: a note on the Dutch experience. Long Range Planning, 37(4), 335349. https://doi.org/10.1016/j. lrp.2004.04.007

5. Çakmak, Z., \& Akgün, I. H. (2018). A theoretical perspective on the case study method. Journal of Education and Learning, 7(1), 96-102. http://doi.org/10.5539/jel. v7n1p96

6. Donaldson, L. (2001). The contingency theory of organizations. London: Sage.

7. Franco-Santos, M., Lucianetti, L., \& Bourne, M. (2012). Contemporary performance measurement systems: A review of their consequences and a framework for research. Management Accounting Research, 23(2), 79-119. https://doi. org/10.1016/j.mar.2012.04.001

8. Guenther, T. W., \& Heinicke, A. (2019). Relationships among types of use, levels of sophistication, and organizational outcomes of performance measurement systems: The crucial role of design choices. Management Accounting Research, 42, 1-25. https://doi. org/10.1016/j.mar.2018.07.002

9. Hair, J. F., Risher, J. J., Sarstedt M., \& Ringle, C. M. (2019). When to use and how to report the results of PLS-SEM. European Business Review, 31(1), 2-24. https://doi. org/10.1108/EBR-11-2018-0203

10. Henri, J.-F. (2006a). Management control systems and strategy: A resource-based perspective. Accounting, Organizations and Society, 31(6), 529-558. https://doi. org/10.1016/j.aos.2005.07.001
11. Henri, J.-F. (2006b). Organizational culture and performance measurement systems. Accounting, Organizations and Society, 31(1), 77-103. https://doi.org/10.1016/j. aos.2004.10.003

12. Henseler, J., Ringle, C. M., \& Sarstedt, M. (2015). A new criterion for assessing discriminant validity in variancebased structural equation modelling. Journal of the Academy of Marketing Science, 43, 115-135. https://doi.org/10.1007/s11747014-0403-8

13. Hiebl, M. R., \& Richter, J. F. (2018). Response Rates in Management Accounting Survey Research. Journal of Management Accounting Research, 30(2), 59-79. https://doi. org/10.2308/jmar-52073

14. Ittner, C. D., Larcker, D. F., \& Randall, T. (2003). Performance Implications of Strategic Performance Measurement in Financial Services Firms. Accounting, Organizations and Society, 28(7-8), 715-741. https://doi.org/10.1016/S03613682(03)00033-3

15. Kaplan, R., \& Norton, D. (1992). The Balanced Scorecard Measures That Drive Performance. Harvard Business Review, 79. Retrieved from https://hbr. 
org/1992/01/the-balancedscorecard-measures-that-driveperformance- 2

16. Kaplan, S. K., \& Mikes, A. (2014). Towards a Contingency Theory of Enterprise Risk Management (Working Paper No. 13-063). Retrieved from https://www. hbs.edu/faculty/Publication $\% 20$ Files/13-063_5e67dffe-aa5e-4faca746-7b3c07902520.pdf

17. Kazár, K. (2013). PLS Path analysis and its application for the examination of the psychological sense of a brand community. Procedia Economics and Finance, 17, 183-191. https://doi.org/10.1016/S22125671(14)00893-4

18. Koufteros, X., Verghese, A. J., \& Lucianetti, L. (2014). The effect of performance measurement systems on firm performance: A cross-sectional and a longitudinal study. Journal of Operations Management, 32(6), 313336. https://doi.org/10.1016/j. jom.2014.06.003

19. Lopez-Valeiras, E., GonzalezSanchez, M. B., \& Gomez-Conde, J. (2016). The effects of the interactive use of management control systems on process and organizational innovation. Review of Managerial Sciences, 10, 487510. https://doi.org/10.1007/ s11846-015-0165-9

20. Mohamed, R., Hui, W. S., Rahman, I. K. A., \& Aziz, R. A. (2014). The relationship between strategic performance measurement system and organizational capabilities: The role of beliefs and boundary control systems. Asian Journal of Business and Accounting, 7(1), 107-142. Retrieved from https:// ajba.um.edu.my/article/view/2688

21. Nisha, N. (2017). An Empirical Study of the Balanced Scorecard Model: Evidence from Bangladesh. International Journal of Information Systems in the Service Sector, 9(1), 68-84. https://doi. org/10.4018/IJISSS.2017010105

22. Owolabi, F. O., Adetula, D. T., \& Taleatu, A. (2016). Balanced score card and performance evaluation in Small and Medium Enterprises (SMEs) in Nigeria. In Proceedings of the 28th International Business Information Management Association Conference, 9-10 November 2016, Seville, Spain.

23. Oyerinde, D. T. (2011). Value- relevance of accounting information in the Nigerian stock market (Doctoral Thesis). Covenant University, Nigeria. Retrieved from https://www. academia.edu/3208940/Value_ Relevance_of_Accounting_Information_in_the_Nigeria_Stock_ Market

24. Oyerogba, E. O. (2015). Management accounting practices in the developing economies: The case of Nigerian listed companies. Journal of Accounting and Management, 5(2), 76-85. Retrieved from http://journals. univ-danubius.ro/index.php/jam/ article/view/2791

25. Simons, R. (1995, MarchApril). Control in an Age of Empowerment. Harvard Business Review. Retrieved from https://hbr. org/1995/03/control-in-an-age-ofempowerment

26. Simons, R. (2000). Performance Measurement \& Control Systems for Implementing Strategy. Prentice Hall: Upper Saddle River, New Jersey.

27. Soderberg, M., Kalagnanam, S., Sheehan, N. T., \& Vaidyanathan, G. (2011). When is a balanced scorecard a balanced scorecard? International Journal of Productivity and Performance Management, 60(7), 688-708. https://doi. org/10.1108/17410401111167780

28. Speckbacher, G., Bischof, J., \& Pfeiffer, T. (2003). A descriptive analysis on the implementation of balanced scorecards in Germanspeaking countries. Management Accounting Research, 14(4), 361387. https://doi.org/10.1016/j. mar.2003.10.001

29. Tuomela, T. (2005). The interplay of different levers of control: A case study of introducing a new performance measurement system. Management Accounting Research, 16(3), 293-320. https://doi. org/10.1016/j.mar.2005.06.003
30. Uwuigbe, U. (2011). An empirical investigation of the association between firms' characteristics and corporate social disclosures in the Nigerian financial sector. Journal of Sustainable Development in Africa, 13(1), 60-74. Retrieved from http://eprints.covenantuniversity.edu.ng/1574/1/AN\%20 EMPIRICAL\%20INVESTIGATION\%20OF\%20THE\%20ASSOCIATION\%20BETWEEN\%20 FIRMS\%E2\%80\%99\%20CHARACTERISTICS\%20AND.pdf

31. Webster, C. (2006). An empirical analysis of the relationships between the interactive use of performance measurement systems, creativity and performance: the intervening role of psychological empowerment (Working Paper). Retrieved from https://www.semanticscholar.org/ paper/An-empirical-analysis-ofthe-relationships-between-Webster /0eee44ef7d902b77177201bc35964 f148ac258e2

32. Weill, P., \& Olson, M. H. (1989). An assessment of the contingency theory of MIS. Journal of Management Information Systems, 6(1), 59-86. https://doi.org/10.108 0/07421222.1989.11517849

33. Widener, S. K. (2007). An empirical analysis of the levers of control framework. Accounting, Organizations and Society, 32(7-8), 757-788. https://doi.org/10.1016/j. aos.2007.01.001 


\section{APPENDIX A}

Table A1. List of Indicators in the Final Structural Model

\begin{tabular}{|c|c|c|}
\hline CONSTRUCT & CODE & INDICATORS \\
\hline \multirow{4}{*}{ Design of PMI } & DSN1 & The strategy of our organisation is well defined \\
\hline & DSN2 & $\begin{array}{l}\text { Our multidimensional performance measurement system combines } \\
\text { financial and non-financial performance measures }\end{array}$ \\
\hline & DSN3 & $\begin{array}{l}\text { Our multidimensional performance measurement system allows } \\
\text { additionally to define target values and action plans }\end{array}$ \\
\hline & DSN4 & $\begin{array}{l}\text { We use the performance measurement system to compensate/reward } \\
\text { some or all the employees }\end{array}$ \\
\hline \multirow{4}{*}{ Diagnostic use } & DGU1 & Track progress towards goals \\
\hline & DGU2 & Monitor results \\
\hline & DGU3 & Compare outcomes to expectations \\
\hline & DGU4 & Review key measures \\
\hline \multirow{7}{*}{ Interactive use } & IUE1 & PMS enables discussion in meetings of superiors, subordinates and peers \\
\hline & IUE2 & $\begin{array}{l}\text { PMS enables continual challenge and debate underlying data, assumptions } \\
\text { and action plans }\end{array}$ \\
\hline & IUE3 & PMS is used to provide a common view of the organisation \\
\hline & IUE4 & To tie the organisation together \\
\hline & IUE5 & To enable the organisation to focus on common issues \\
\hline & IUE6 & To enable the organisation to focus on critical success factors \\
\hline & IUE7 & To develop a common vocabulary in the organisation \\
\hline \multirow{3}{*}{ Customer Perspective construct } & CPE1 & Customer Response Time \\
\hline & CPE2 & On Time Delivery \\
\hline & CPE3 & Survey of Customer Satisfaction \\
\hline \multirow{5}{*}{ Learning and growth } & LGP1 & Introduction of new patents \\
\hline & LGP2 & Introduction of new product/service launches \\
\hline & LGP3 & Time-to-market for new products \\
\hline & LGP4 & Employee satisfaction \\
\hline & LGP5 & Investments in new technology \\
\hline \multirow{3}{*}{ Internal business process } & IBP1 & Speed of adopting innovations already introduced in the market \\
\hline & IBP2 & Effective provision of services \\
\hline & IBP3 & Cross-functional communication flow throughout the organisation \\
\hline \multirow{4}{*}{ Financial perspective } & FPE1 & Operating income \\
\hline & FPE2 & Return-on-investment (ROI) \\
\hline & FPE3 & Return-on-equity (ROE) \\
\hline & FPE4 & Net cash flows \\
\hline
\end{tabular}

